Nabarro, J.D.N., Moxham, A., Walker, G. \& Slater J.D.H. (1957) Rectal hydrocortisone. British Medical Journal, 2, 272.

Nilsson, I.M., Anderson, L. \& Buorkman, E. (1966) Epsilon-aminocaproic acid as a therapeutic agent based on 5 years' clinical experience. Acta medica scandinavica, Suppl. 448.
SAlter, R.H. \& ReAD, A.E. (1970) Epsilon-aminocaproic acid therapy in ulcerative colitis. Gut, 11, 585.

Sampson, P.A. \& BROOKe, B.N. (1963). Absorption of hydrocortisone from the large bowel. Lancet, i, 701 .

SWEENEY, W.M. (1965) Aminocaproic acid, an inhibitor of fibrinolysis. American Journal of Medical Sciences, 249, 576.

Postgraduate Medical Journal (July 1972) 48, 442-445.

\title{
Eosinophilic leukaemia
}

\author{
N. IsLAM \\ M.B., F.R.C.P.(Ed)., F.C.P.S. \\ A. K. M. B. KARIM \\ M.B., B.S., D.T.M.\&H., M.R.C.P.(Glas. \& Edin).
}

\author{
K. M. RAHMAN \\ M.B., B.S., M.Sc., D.B., D.Path., M.R.C.Path.
}

Institute of Postgraduate Medicine, Dacca-2, Bangladesh

MARKED leucocytosis with eosinophilia in the peripheral blood can occur due to various causes which may be either benign or malignant (Islam, 1964). It is therefore very difficult at times to establish the diagnosis of eosinophilic leukaemia.

In spite of earlier doubt about the existence of eosinophilic leukaemia as a distinct entity (Dameshek \& Gunz, 1964) it is now established that it does exist. According to Chen \& Smith (1960) less than thirty cases were reported by 1957 . Wintrobe (1967) states that 100 cases have been described of which Bentley et al. (1961) could accept only twenty as true cases of eosinophilic leukaemia. These authors also reported a case of their own with their review. Evidently true cases of eosinophilic leukaemia are extremely rare.

\section{Case report}

F.A. 11 years, a school student from Dacca came to one of us (N.I.) on 2 November 1968 with a history of cough with scanty expectoration, fever $\left(100^{\circ} \mathrm{F}\right)$ and vague abdominal discomfort for the previous 3 weeks.

On examination there was no abnormality except a few scattered rales on both sides of the chest. A chest $\mathrm{X}$-ray was not abnormal while the blood count showed a leucocyte count of $100,000 / \mathrm{mm}^{3}$ with $80 \%$ eosinophils. A tentative diagnosis of tropical eosinophilia was made. Diethylcarbamazin $400 \mathrm{mg}$ a day for 2 weeks was advised. Three weeks later on reexamination the child showed no sign of improvement but was anaemic and presumably had lost some weight. Axillary lymph nodes were enlarged and there was sternal tenderness. Liver was $25 \mathrm{~cm}$ and spleen $5 \mathrm{~cm}$ below the costal margins. A week later he was admitted under one of us (N.I.) in the Institute of Postgraduate Medicine, Dacca (4 December 1968) when an infiltrate in the right fundus was discovered. His total leucocyte count was found to be $190,000 /$ $\mathrm{mm}^{3}$ with $96 \%$ eosinophils. Filarial complement fixation test (FCFT) was negative. A diagnosis of eosinophilic leukaemia was made. A lymph node was removed and sent to Professor C. V. Harrison of the Royal Postgraduate Medical School, London. Meanwhile therapy was started with prednisone and 6-mercaptopurine which was continued for about 4 weeks followed by Myleran and parenteral hydrocortisone. Microscopically the lymph node was found to retain its normal architectural pattern. Scattered through the node there were numerous eosinophil granulocytes. The majority of these were fully differentiated leucocytes and the rest were eosinophil myelocytes which Professor Harrison thought was consistent with the clinical diagnosis of eosinophilic leukaemia.

On request from his relations the boy was then sent to the Royal Postgraduate Medical School where he was admitted on 5 February 1969.

\section{Investigations}

Peripheral blood. WBC, $21,000 / \mathrm{mm}^{3}$; neutrophils, $12 \%$; eosinophils, $72 \%$; lymphocytes, $15 \%$; monocytes, $1 \%$; Hb, $7 \mathrm{~g} / 100 \mathrm{ml}$; reticulocytes, $1 \%$; PCV, $23 \%$; MCHC, $30 \%$; platelets, $63,000 / \mathrm{mm}^{3}$. 
TABLE 1. Laboratory data (peripheral blood and bone marrow)

\begin{tabular}{|c|c|c|c|c|c|c|}
\hline & 2 March 1968 & 4 Dec. 1968 & 5 Feb. 1969 & 4 March 1969 & 7 March 1969 & 13 March 1969 \\
\hline \multicolumn{7}{|l|}{ Peripheral blood } \\
\hline Platelets & & - & 63,000 & - & 35,000 & 23,000 \\
\hline Total $\mathrm{WBC} / \mathrm{mm}^{3}$ & 100,000 & 90,000 & 21,000 & 95,000 & 8000 & - \\
\hline Neutrophils & - & - & $12 \%$ & - & - & - \\
\hline Eosinophils & $80 \%$ & $96 \%$ & $\begin{array}{l}72 \% \text { (occa- } \\
\text { sional early } \\
\text { forms) }\end{array}$ & - & - & - \\
\hline Lymphocytes & - & - & $15 \%$ & - & - & - \\
\hline Monocytes & - & - & $1 \%$ & - & - & - \\
\hline Blast cells $/ \mathrm{mm}^{3}$ & - & Nil & $\mathrm{Nil}$ & 46,500 & Nil & - \\
\hline \multirow[t]{2}{*}{ Eosinophils $/ \mathrm{mm}^{3}$} & - & - & - & 16,000 & 一 & - \\
\hline & & & 10 Feb. 1969 & 4 March 1969 & 10 March 1969 & \\
\hline \multicolumn{7}{|l|}{ Bone marrow } \\
\hline Erythropoiesis & & & Normoblastic & - & - & \\
\hline Leucopoiesis & & & $\begin{array}{l}\text { Predominance } \\
\text { of mature } \\
\text { eosinophils }\end{array}$ & - & - & \\
\hline Blast cells & & & No excess & $\begin{array}{l}\text { Complete } \\
\text { blast cell } \\
20 \% \\
\text { infiltration }\end{array}$ & 一 & \\
\hline Megakaryocytes & & & Present & - & - & \\
\hline Plasma cells & & & Not increased & 一 & 一 & \\
\hline
\end{tabular}

Bone marrow showed normoblastic erythropoiesis. Many binucleated and bizarre forms were seen. There was a predominance of mature but abnormal eosinophils many of which have peleger-like nuclei and degranulated cytoplasm. Neutrophil precursors are not conspicuous but appeared normal. No excess of blast cells were seen.

Serum immunoglobulins: raised IgA. Blood WR negative. Mantoux $1: 1000$ negative. Nose and throat swabs: growth of Staph. aureus. Urine: no deposit, no growth. Blood for microfilaria: none seen. Sputum: no parasites, ova or cysts seen. Urine: no Schistosoma ova found.

Chest X-ray: patchy opacities throughout both lung fields. Toxocara skin test was positive but the serological test for Toxocara and Filaria were both negative.

For several weeks after admission the child remained well. Therapy with diethylcarbamazine was started again. Steroid therapy was gradually withdrawn. Hookworm ova in his stool were treated with Alcopar and Giardia lamblia by Mepacrine. Three weeks after admission he developed bilateral parotid swelling with rise of temperature, increasing hepatosplenomegaly and purpuric spots. On 4 March 1969 his total leucocyte was $95,000 / \mathrm{mm}^{3}$ with 46,500 blast cells and 16,000 eosinophils $/ \mathrm{mm}^{3}$ (Fig. 1). A bone marrow at this stage showed complete blast cell infiltration (Fig. 2). He was advised prednisolone 40 $\mathrm{mg}$ daily and rubidomycin i.v.i. for 2 consecutive days which resulted in marked clinical improvement. There was regression of hepatosplenomegaly and the total leucocyte count was $8000 / \mathrm{mm}^{3}$ with no blast cells on 7 March 1969. Platelet count was 35,000 $\mathrm{mm}^{3}$. Examination of bone marrow on 10 March 1969 showed $20 \%$ blast cells.

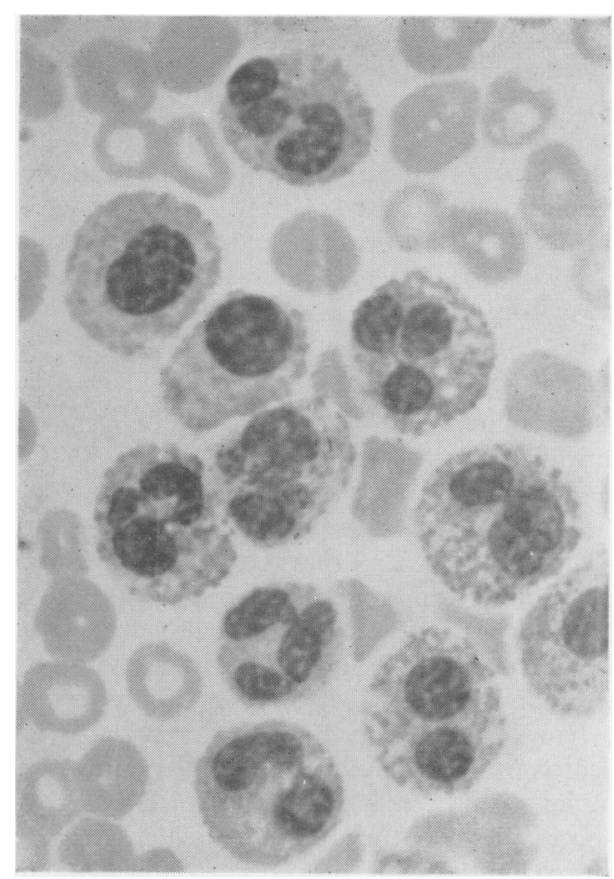

FIG. 1. Peripheral blood film showing pleomorphic eosinophils. 


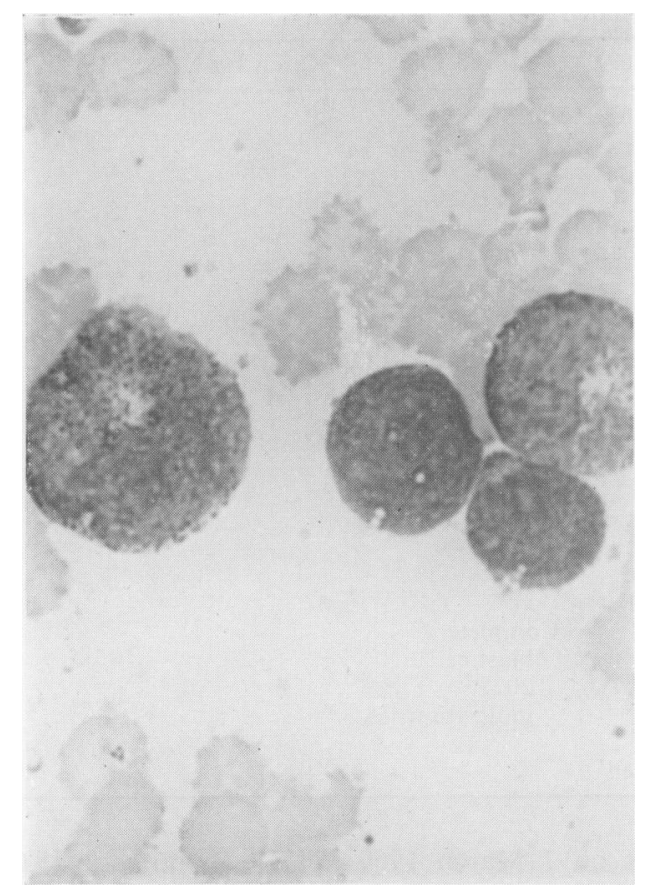

FIG. 2. Bone marrow showing blast cells.

The boy was discharged on 14 March 1969 with the advice to continue prednisolone $40 \mathrm{mg}$, nystatin suspension 800,000 units and cloxacillin $1000 \mathrm{mg}$ daily.

On 20 March 1969 he was re-admitted in our hospital. During the subsequent few days his condition rapidly deteriorated. Chest X-ray: opacities in both lung fields, more marked in the right hilar region (Fig. 3). A week later the child died. No necropsy could be performed.

\section{Discussion}

Eosinophilic leukaemia is undoubtedly a rare condition and many cases have been wrongly described in the absence of any specific criteria laid down for the diagnosis, because of a wide range of conditions giving rise to marked leucocytosis with eosinophilia. Even benign condition like tropical eosinophilia can be associated with an increased number of eosinophils in the peripheral blood and eosinophilic infiltrations in various organs, e.g. liver, lung, lymph node and bone marrow etc. (Islam, 1964). It is therefore not surprising that only twentyone cases could be accepted as true eosinophilic leukaemia till recently after a critical review of the literature (Bentley et al., 1961). The criteria laid down by these authors are 'a marked eosinophilia in the peripheral blood with blast cells above normal in the

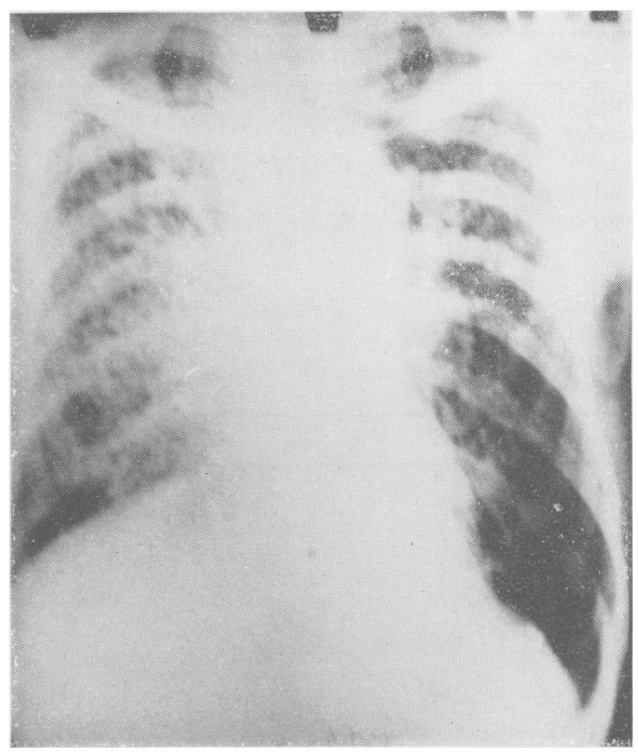

Fig. 3. Chest X-ray showing opacities in the lung fields more marked on the right.

bone marrow and/or peripheral blood during the course of the illness'.

The case we have presented here undoubtedly fulfils these criteria. An analysis of laboratory findings? (Table 1) indicates that our case belong to the second group described by Bentley et al. (1971), who divided the accepted twenty cases of eosinophilic leukaemia into two different groups (i) Acute blastic type (nine cases), (ii) mature cell presentation assuming an acute course (five cases) or a chronic course (six cases). At the initial stage our case had only mature cells which went into blastic transformation within a short period of a few weeks. One might argue whether the diagnosis was justified during the earlier period of the disease when no blast cell could be demonstrated, though in fact we strongly suspected the condition for several reasons. The symptoms with which the child presented to us were of short duration. This could very well fit in with another common condition associated with marked leucocytosis and eosinophilia: a total leucocyte cannot of 90,000 and as high as $90 \%$ eosinophilia in the peripheral blood have been recorded in tropical eosinophilia (Islam, 1964). Diethylcarbamazine therapy was instituted at this stage as this could be another extreme case of tropical eosinophilia. There was however no improvement in the condition, the child progressively deteriorating and his blood count rising to $190,000 / \mathrm{mm}^{3}$ with $96 \%$ eosinophils. At this stage we could not conceive of any other possibility except leukaemia. Presence of sternal tenderness and some infiltrate in the right 
fundus which have never been described in association with tropical eosinophilia strengthened our suspicion and we decided to start treatment with steroids and antileukaemic drugs, e.g. 6-mercaptopurine and Myleran. Enlargement of lymph nodes, sternal tenderness and leukaemic retinitis have been descrited in association with eosinophilic leukaemia (Norlander, 1951).

Odeberg (1965) after a critical review of the literature was unable to find a single case of uncomplicated eosinophilic leukaemia and found evidence of multi-system involvement some time or other. According to him eosinophilic leukaemia and disseminated eosinophilic collagen disease (DECD) may be variants of the same condition. Pulmonary infiltration as revealed in the serial X-rays, enlargement of the lymph nodes, sternal tenderness, ocular changes and hepatosplenomegaly in our case undoubtedly point towards widespread involvement of various organs, consistent with the description of Engfeldt \& Zetterstroms (1965) who considered this as a separate entity. We feel that our case satisfies the criteria of both these groups of workers and provides additional evidence that eosinophilic leukaemia and disseminated eosinophilic collagen disease are but two stages or aspects of the same disease.

\section{Acknowledgments}

We are extremely grateful to Professor C. V. Harrison for the microscopic study of the lymph node and his generous help in getting the child admitted in the Royal Postgraduate Medical School. We are no less grateful to Professor J. V. Dacie and Dr Scopes who very kindly sent us the case note summary covering the period of their supervision. It would have been impossible to publish this without their help and co-operation.

\section{References}

Bentley, H.P. JR., ReARdon, A.E., KNoedler, J.P. \& Krivit, W. (1961) Eosinophilic leukemia. American Journal of Medicine, 30, 310.

Chen, H.P. \& Sмiтh, H.S. (1960) Eosinophilic leukemia. Annals of Internal Medicine, 52, 1343.

DAmeshek, W. \& Gunz, F. (1964) Leukaemia, 2nd edn, p. 226, Grune and Stratton, New York.

ENGFELDT, B. \& ZetTERSTROM, R. (1956) Disseminated eosinophilic collagen disease. Acta medica scandinavica 153, 337.

Islam, N. (1964) Tropical Eosinophilia, p. 62. Postgraduate Medicine, Dacca, Bangladesh.

Norlander, N.B. (1951) Eosinophilic leukemia infiltrating the Gasserian ganglion. Acta medica scandinavica, 177, 129.

Odeberg, B. (1965) Eosinophilic leukemia and disseminated eosinophilic collagen disease-a disease entity? Acta medica scandinavica, 177, 129.

Wintrobe, M.M. (1967) Clinical Haematology, 6th edn, p. 1022. Lea \& Febiger, Philadelphia.

\title{
Haemorrhage and fever in the Munchausen syndrome
}

\author{
J. C. ANDERSON \\ M.B., M.R.C.P.
}

\author{
P. W. EWAN \\ M.B., B.S.
}

\author{
N. D. COMPSTON \\ M.D., F.R.C.P.
}

\section{Royal Free Hospital, Lawn Road, London, N.W.3}

A CASE of the Munchausen syndrome (Asher, 1951) is described, the main features of which were recurrent gastro-intestinal haemorrhage and later, a pyrexia of unknown origin.

\section{Case report}

In 1961, at the age of 24 years, the patient, a staff nurse, began to complain of intermittent epigastric pain sometimes related to meals. Initial investigations, which included a barium meal, showed no abnormality.

The symptoms persisted, and 2 years later the pain was followed by haematemesis. For the next 4 years shehad intermittent haematemesis and melaena which often resulted in substantial blood loss, and required frequent transfusion.

During this time she was extensively and repeatedly investigated both in her own hospital and in a specialist unit. Repeated barium radiography, gastroscopy etc. were normal, and no bleeding diathesis was demonstrated. Two exploratory laparotomies revealed no abnormality after a thorough examination of the whole gastro-intestinal tract.

Two and a half years after the onset of symptoms an elective vagotomy and pyloroplasty was performed. A small, healing acute duodenal ulcer was 